\title{
PREDIKSI RISIKO SISTEMATIK SAHAM-SAHAM LQ45 BURSA EFEK INDONESIA
}

\author{
A An Arief Jusuf \\ Fakultas Ekonomi Universitas Widya Kartika Surabaya \\ aanjusuf@gmail.com
}

\begin{abstract}
Beta has been argued, both conceptually as well as empirically. In 1960's, many practitioners used superior advantages in calculation attempted atCAPM theory for investing in asset which has high Beta. Many empirical researches on the later years refused the existence of security market line from CAPM. Afterwards, many practitioners and academicians stated the death of CAPM. Linear regression method could be used to make decision if it had already matched the criteria for Best Linear Unbiased Estimator. Prediction model is a statistic testing which aimsat knowing whether there is a relationship or effect between researched variables. Nonparametric method is an alternative action which is taken when the research model does not match normality assumption. This research, as shown by the use of weekly data, could be free from technical trading problems in predicted systematic risk. While ASII, HRUM, and TLKM stock returns are affected more by other factors. This condition has caused systematic risk not to affect significantly on those stocks. Another result has shown that banking stocks, which became part of LQ45, have higher systematic risk respectively.
\end{abstract}

Keywords: CAPM, linear regression method, best linear unbiased estimator and non-parametric method

\section{PENDAHULUAN}

Dalam konteks investasi, risiko yang dianggap relevan adalah risiko yang tidak dapat dihilangkan (risiko sistematik) yang lebih dikenal dengan istilah Beta. Beta sudah banyak digunakan baik dalam penelitian, maupun dalam praktik namun hasilnya tidak konsisten. Hasil yang tidak konsisten tersebut dapat terjadi karena ketidakakuratan dalam membuat estimasi Beta (Tandelilin 2003). Penelitian ini menitikberatkan pada tujuan mengestimasi dan memprediksi Beta. Konsep Beta atau yang sering dikenal melalui teori Capital Asset Pricing Model masih banyak digunakan dalam Manajemen Keuangan dan Investasi. Risiko yang dapat dihilangkan dengan melakukan diversifikasi disebut risiko taksistematik (unsystematic risk), sedangkan risiko yang tidak dapat dihilangkan dengan melakukan diversifikasi disebut risiko sistematik (systematic risk) atau lebih dikenal 
dengan istilah Beta $(\beta)$. Sejak diperkenalkan pertama kali, teori Capital Asset Pricing Model (CAPM) dan Beta terus diperdebatkan baik secara konseptual maupun empiris. Ketidaktepatan dalam pengukuran Beta akan menimbulkan masalah dalam mendesain penelitian maupun penggunaannya dalam praktik. Estimasi Beta merupakan pusat untuk banyak keputusan finansial, terkait juga dengan manajemen portofolio, penganggaran modal dan penilaian performa (Bartholdy dan Peare 2001). Beta juga merupakan variabel kunci dalam dunia akademik. Beta digunakan untuk menguji model penilaian aset dan efisiensi pasar.

CAPM menarik karena logika sederhana yang kuatdan secara intuisi memenuhi prediksi pengukuran risiko dan menjelaskan mengenai hubungan antara tingkat keuntungan yang diharapkan dengan risiko. Hal yang disayangkan, mungkin karena kesederhanaannya, catatan empiris mengenai model ini benar-benar kurang baik (Fama dan French 2003). Model empiris merefleksikan kegagalan model tersebut. Pada akhir tahun 1960-an, banyak praktisi menggunakan keunggulan kekuatan perhitungan yang superior pada waktu itu mencoba untuk menempatkan teori $C A P M$ untuk menempatkan investasi pada aset yang memiliki Beta tinggi. Mereka berharap aset-aset tersebut akan menghasilkan tingkat pengembalian yang tinggi setelah investasi, tetapi mereka sepenuhnya dikecewakan (Malkiel 1990 dan Bernstein 1992). Pada masa itu para akademisi baru saja mulai meneliti mengenai validitas dari $C A P M$. Penelitian terkait dengan $C A P M$ dalam jumlah besar terjadi pada waktu itu (Fama et al.,1969) yang mendukung garis pasar sekuritas dari CAPM (Fama 1971). Banyak penelitian empiris pada tahun-tahun berikutnya (Chan et al.,1991; Fama dan French 1992) menolak keberadaan garis pasar sekuritas dari $C A P M$. Sejak saat itu banyak para praktisi dan para akademisi menyatakan " $C A P M$ dead' (Fan 2004).

Penelitian mengenai risiko sistematik telah banyak dilakukan oleh banyak peneliti di dalamdan di luar negeri. Pada umumnya untuk penelitian di dalam negeri belum banyak yang mempertimbangkan permasalahan uji asumsi klasik dalam mengukur risiko sistematik. Metoda regresi linier dapat digunakan untuk pengambilan keputusan jika telah memenuhi kriteria Best Linear Unbiased Estimator. Seiring dengan perkembangan perangkat lunak dan ilmu pengetahuan, maka permasalahan uji asumsi klasik yang meliputi normalitas, multikolinearitas, heteroskedastisitas dan autokorelasi tidak dapat diabaikan.

Risiko merupakan suatu hal yang dipahami banyak pelaku pasar modal. Pelaku pasar modal memiliki preferensi risiko yang berbeda satu dengan yang lain. Sikap investor terhadap risiko sangat tergantung pada preferensi mereka terhadap risiko. Investor yang lebih berani (less risk averse) cenderung memilih investasi yang berisiko tinggi dengan harapan akan memperoleh return yang tinggi pula. Sebaliknya, investor yang tidak mau menanggung risiko investasi tinggi (more risk averse) akan kecil pula kemungkinannya mendapat return tinggi (Tandelilin 2003). Saham-saham yang termasuk dalam Indeks LQ45 sering menjadi referensi bagi investor dikarenakan merupakan kumpulan saham-saham aktif ditransaksikan dengan nilai yang tinggi, memiliki kondisi keuangan yang bagus, dan berprospek 
untuk mengalami pertumbuhan. Sebelum melakukan transaksi para pelaku pasar modal perlu mempertimbangkan risiko sistematik dari saham yang akan dibeli.

Permasalahan multikolinearitas dapat dihindari dalam prediksi risiko sistematik karena penggunaan persamaan regresi linier sederhana. Dengan adanya metoda alternatif, yaitu Partial Least Square, maka permasalahan normalitas dalam Ordinary Least Square dapat diselesaikan dengan metodaPartial Least Square. Selama memenuhi kriteria Best Linear Unbiased Estimator, maka metoda alternatif Partial Least Square tidak digunakan. Dalam penelitian yang pernah dilakukan menunjukkan pengembalian saham pada Bursa Efek Jakarta (masa itu) tidak memiliki distribusi normal (Manurung 1996). Metodanon-parametric lebih sesuai untuk menguji keberadaan $C A P M$.

\section{TUJUAN PENELITIAN}

Tujuan dari penelitian ini adalah sebagai berikut:

1. memprediksi risiko sistematik saham-saham LQ45 berdasarkan metodaOrdinary Least Square,

2. memprediksi risiko sistematik saham-saham LQ45 berdasarkan metodaPartial Least Square untuk model persamaan yang terkendala dengan permasalahan normalitas.

\section{TINJAUAN TEORI}

\section{Model Indeks Tunggal}

Model indeks tunggal dapat digunakan untuk menyederhanakan perhitungan dengan model Markowitz. Model ini didasarkan pada pengamatan bahwa harga dari suatu sekuritas berfluktuasi searah dengan indeks harga pasar. Secara khusus dapat diamati bahwa kebanyakan saham cenderung mengalami kenaikan harga jika indeks harga saham naik, begitu pula sebaliknya. Hal ini menyiratkan pengembalian dari sekuritas-sekuritas mungkin berkorelasi karena adanya reaksi umum terhadap perubahan-perubahan nilai pasar (Hartono 2009). Berikut persamaan indeks pasar:

$$
R_{i}=\alpha_{i}+\beta_{i} R_{M}
$$

\footnotetext{
Keterangan:

$\mathrm{R}_{\mathrm{i}} \quad=$ return sekuritas ke-i

$\alpha_{\mathrm{i}}=$ suatu variabel acak yang menunjukkan komponen dari return sekuritas ke-i yang independen terhadap kinerja pasar

$\beta_{\mathrm{i}} \quad=$ Beta yang merupakan koefisien yang mengukur perubahan Ri akibat dari perubahan $\mathrm{R}_{\mathrm{M}}$ $\left(\mathrm{R}_{\mathrm{M}}\right.$ : tingkat return dari indeks pasar).
} 


$$
R_{M, t}=\frac{I H S G_{t}-I H S G_{t-1}}{I H S G_{t-1}}
$$

Keterangan:

$\mathrm{R}_{\mathrm{M}, \mathrm{t}} \quad=$ tingkat return dari indeks pasar pada waktu ke-t.

$\mathrm{IHSG}_{\mathrm{t}}=$ Indeks Harga Saham Gabungan pada waktu ke-t.

$\mathrm{IHSG}_{\mathrm{t}-1}=$ Indeks Harga Saham Gabungan pada waktu ke-t-1.

Untuk menghitung tingkat pengembalian saham biasa yang membayar dividen periodik sebesar $D_{t}$ rupiah/ lembar, maka (Hartono 2009):

$$
R_{i, t}=\frac{P_{i, t}-P_{i, t-1}+D_{i, t}}{P_{i, t-1}}
$$

Keterangan:

$\mathrm{R}_{\mathrm{i}, \mathrm{t}} \quad=$ tingkat return dari saham i pada waktu ke-t.

$\mathrm{P}_{\mathrm{i}, \mathrm{t}} \quad=$ harga saham i pada waktu ke-t.

$\mathrm{P}_{\mathrm{t}-1} \quad$ = harga saham i pada waktu ke-t-1.

$\mathrm{D}_{\mathrm{i}, \mathrm{t}} \quad=$ dividen saham i pada waktu ke-t.

\section{Beta}

Beta merupakan suatu pengukur volatilitas return suatu sekuritas atau return portofolio terhadap return pasar. Beta sekuritas ke-i mengukur volatilitas return sekuritas ke-i dengan return pasar. Beta portofolio mengukur volatilitas return portofolio dengan return pasar. Dengan demikian Beta adalah pengukur risiko sistematik dari suatu sekuritas atau portofolio relatif terhadap risiko pasar (Hartono 2009).

Beta dapat dihitung dengan menggunakan teknik regresi. Teknik regresi untuk mengestimasi Beta suatu sekuritas dapat dilakukan dengan menggunakan return sekuritas sebagai variabel dependen dan return pasar sebagai variabel independen. Persamaan regresi yang dihasilkan dari data time series ini akan menghasilkan koefisien Beta yang diasumsikan stabil dari waktu ke waktu selama periode observasi. Persamaan regresi yang digunakan untuk mengestimasi Beta didasarkan pada model indeks tunggal atau indeks pasar berdasarkan persamaan berikut:

$$
R_{i}=\alpha_{i}+\beta_{i} R_{M}+e_{i}
$$

Dari persamaan di atas, koefisien $\beta_{\mathrm{i}}$ merupakan Beta sekuritas i yang diperoleh dari teknik regresi. Variabel acak $e_{i}$ pada persamaan regresi menunjukkan bahwa persamaan linier yang dibentuk mengandung kesalahan. 


\section{Perbandingan Model Estimasi dan Model Prediksi}

Model estimasi merupakan pengujian statistika yang bertujuan mengestimasi model teoritikal yang dibangun dengan mengukur kelaikan model pada jenjang variabel laten dan parameter yang diestimasi atau indikatornya. Konsekuensi penggunaan model estimasi adalah pengujian menuntut basis teori yang kuat, berbagai asumsi yang kaku dan kelaikan model menjadi ukuran utama. Pengujian model estimasi harus menggunakan teknik analisis berbasis kovarian, misalnya SEM Lisrel atau AMOS (Hartono dan Abdillah 2009).

Model prediksi adalah pengujian statistika yang bertujuan menguji efek prediksi antar variabel laten untuk mengetahui adanya hubungan atau pengaruh antar variabel yang diteliti. Konsekuensi penggunaan model prediksi adalah pengujian dapat dilakukan tanpa dasar teori yang kuat, mengabaikan beberapa asumsi dan parameter ketepatan model prediksi dilihat dari nilai koefisien determinasi. Pengujian model prediksi dapat dilakukan dengan menggunakan teknik analisis statistika berbasis varian, misalnya PLS.

\section{Ordinary Least Square}

Ordinary Least Square (OLS) adalah bagian dari Least Square Method(LSM) yang merupakan suatu teknik statistik paling popular digunakan dalam penelitian empiris. Hal tersebut disebabkan beberapa alasan, antara lain: (1) estimator yang paling umum dapat diukur dengan rerangka LSM; (2) LSM menggunakan persamaan kuadratik yang secara matematis sangat dapat diukur; (3) alat matematika dan algoritma yang terdapat dalam LSM, seperti derivatives dan eigendecomposition (faktorisasi matrik ke dalam format kanonikal yang dipresentasikan dengan nilai eigen dan faktor eigen) telah diteliti, dan dibahas melalui studi dalam waktu yang sangat panjang (Hartono dan Abdillah 2009).

Persamaan regresi linier sederhana: $y=\alpha+\beta \mathrm{x}$, yang mana koefisien $\alpha$ dan $\beta$ akan dicari koefisiennya dari semua data yang diambil. Secara statistik, untuk membuat model menjadi realistik berdasarkan data yang diambil, satu random disturbance termyang disimbolkan dengan $u$ ditambahkan dalam persamaan (Brooks 2008). Persamaan menjadi: $\mathrm{y}_{\mathrm{t}}=\alpha+\beta \mathrm{x}_{\mathrm{t}}+\mathrm{u}_{\mathrm{t}}$ di mana $\mathrm{t}$ adalah nomor observasi.

Estimasi $O L S$ memiliki properti statistika yang kuat dengan kriteria: (1) data diambil melalui penyampelan acak dari populasi yang didefinisi dengan baik; (2) model populasi bersifat linier; (3) kesalahan memiliki nilai ekspektasi sama dengan nol; (4) variabel independen bersifat linier; (5) kesalahan prediksi terdistribusi normaldan tidak berkorelasi dengan variabel independen (asumsi homoskedastisitas); (6) tanpa bias yang sering dikenal dengan Best Linear Unbiased Estimator.

\section{Partial Least Square}

Analisis Partial Least Square (PLS) adalah teknik statistika multivariat yang melakukan pembandingan antara variabel dependen berganda dan variabel independen berganda. PLS adalah salah satu metoda statististika Structural Equation 
Modeling berbasis varian yang didesain untuk menyelesaikan regresi berganda ketika terjadi permasalahan spesifik pada data, seperti ukuran sampel penelitian kecil, adanya data yang hilang dan multikolinearitas. Sebaliknya, regresi Ordinary Least Square menghasilkan data yang tidak stabil ketika data berukuran kecil, adanya data yang hilang dan multikolinearitas antar prediktor sehingga meningkatkan tingkat penyimpangan standar dari koefisien yang diestimasi (Hartono dan Abdillah 2009).

Tabel 1

Perbandingan Analisis antara Partial Least Square dengan Ordinary Least Square

\begin{tabular}{|c|c|c|}
\hline Isu & Partial Least Square & Ordinary Least Square \\
\hline $\begin{array}{l}\text { Tujuan analisis secara } \\
\text { umum }\end{array}$ & $\begin{array}{l}\text { Menguji efek prediksi hipotesis } \\
\text { parsial dan hipotesis model yang } \\
\text { diukur pada jenjang konstruk atau } \\
\text { variabel laten }\end{array}$ & $\begin{array}{l}\text { Menguji efek prediksi hipotesis } \\
\text { parsial yang diukur pada jenjang } \\
\text { variabel laten }\end{array}$ \\
\hline Tujuan analisis varian & $\begin{array}{l}\text { Penjelasan varian variabel dependen } \\
\text { yang diukur dengan parameter } \mathrm{R}^{2}\end{array}$ & $\begin{array}{l}\text { Penjelasan varian model secara } \\
\text { keseluruhan yang diukur dengan } \\
\text { parameter } \mathrm{R}^{2}\end{array}$ \\
\hline Kebutuhan dasar teori & $\begin{array}{l}\text { Mensyaratkan teori walaupun tidak } \\
\text { dengan dasar yang kuat. Tepat untuk } \\
\text { penelitian yang menguji dan/ } \\
\text { mengembangkan teori }\end{array}$ & \\
\hline Distribusi asumsi & $\begin{array}{l}\text { Dapat digunakan pada data yang } \\
\text { terkendala asumsi klasik }\end{array}$ & $\begin{array}{l}\text { Memenuhi asumsi linearitas, } \\
\text { normalitas, tidak ada multikolinearitas } \\
\text { (asumsi klasik) }\end{array}$ \\
\hline $\begin{array}{l}\text { Ukuran sampel } \\
\text { mimimum }\end{array}$ & 10 sampel untuk tiap jalur & 5-10 sampel per konstruk \\
\hline
\end{tabular}

Sumber: Hartono dan Abdillah (2009)

Secara filosofis perbedaan antara covariance based Structural Equation Modelling dengan component based Partial Least Square berasal dari tujuan yang ingin dicapai. Pada kondisi penelitian yang mempunyai dasar teori yang kuat dan pengujian teori atau pengembangan teori sebagai tujuan utama riset, maka metoda dengan covariance based lebih sesuai. Untuk tujuan prediksi pendekatan PLS lebih sesuai. Dengan pendekatan PLS diasumsikan bahwa semua ukuran varian adalah varian yang berguna untuk dijelaskan. PLS menggunakan iterasi algoritma yang terdiri dari seri analisis OLS sehingga persoalan identifikasi model tidak menjadi masalah untuk model recrusive, serta tidak mengasumsikan bentuk distribusi tertentu untuk skala ukuran variabel (Ghozali 2008). Perbandingan analisis antara Partial Least Square dengan Ordinary Least Square dapat dilihat pada Tabel 1.

\section{METODA PENELITIAN}

Penelitian ini menggunakan analisis regresi time series yang diproses dengan bantuan program statistik Eviews dengan prosedur Newey-West yang mana mengkoreksi permasalahan autokorelasi dan heteroskedastisitas yang ada dalam persamaan regresi (Brooks 2008). Permasalahan multikolinearitas tidak muncul 
karena menggunakan model regresi linier sederhana yang mana hanya terdiri dari satu variabel bebas. Tingkat signifikansi yang digunakan $(\alpha)=5$ persen. Sebelum dapat diinterpretasikan, pengujian normalitas menggunakan teknik Jarque-Bera. Jika nilai residual terdistribusi secara normal, angka statistik Jarque-Bera tidak akan menunjukkan angka yang signifikan. p-value yang dihasilkan seharusnya lebih dari 0,05 jika nilai residual terdistribusi secara normal. Linearitas dapat diketahui dari pvalue uji-F. Jika p-value lebih kecil daripada 0,05, maka persamaan regresi yang dihasilkan adalah linier. Kebermaknaan koefisien Beta untuk keluaran persamaan ini dapat diketahui dari p-value untuk uji-t. Jika p-value koefisien Beta sama atau lebih besar daripada 0,05, maka Beta tidak berpengaruh secara signifikan terhadap return saham.

Jika asumsi normalitas tidak terpenuhi, maka dilanjutkan dengan pengolahan data menggunakan bantuan program SMARTPLS Ver: 2.0.M3. Jika keluaran $t_{\text {hitung }}$ koefisien Beta $>t_{\text {tabel }}$ koefisien Beta, maka beta berpengaruh terhadap return saham (koefisien Beta dapat digunakan untuk menginterpretasikan pengaruhnya terhadap return saham). $\mathrm{t}_{\text {tabel }}$ dihitung dengan menggunakan program LibreOffice Calc.

\section{Definisi Operasional}

Model Indeks Tunggal:

$$
R_{i}=\alpha_{i}+\beta_{i} \circ R_{M}+e_{i}
$$

Return saham $\left(\mathrm{R}_{\mathrm{i}}\right)$ adalah return saham mingguan saham LQ45 Bursa Efek Indonesia.

Konstanta $\left(\alpha_{\mathrm{i}}\right)$ adalah suatu variabel acak yang menunjukkan komponen dari return mingguan saham LQ45 Bursa Efek Indonesia yang independen terhadap kinerja pasar. Beta saham $\left(\beta_{\mathrm{i}}\right)$ adalah Beta yang merupakan koefisien yang mengukur perubahan secara mingguan dari return saham akibat dari perubahan pengembalian Indeks Harga Saham Gabungan Bursa Efek Indonesia.

Return Saham:

$$
R_{i, t}=\frac{P_{i, t}-P_{i, t-1}+D_{i, t}}{P_{i, t-1}}
$$

\section{Keterangan:}

Return saham $\left(\mathrm{R}_{\mathrm{it}}\right)$ adalah return saham mingguan saham LQ45 Bursa Efek Indonesia pada minggu ke-t.

Harga saham adalah:

$\mathrm{P}_{\mathrm{i}, \mathrm{t}} \quad$ =harga penutupan saham "i” LQ45 Bursa Efek Indonesia pada periode ke-t, secara mingguan;

$\mathrm{P}_{\mathrm{i}, \mathrm{t}-1} \quad$ =harga penutupan saham "i”" LQ45 Bursa Efek Indonesia pada periode ke-1, secara mingguan.

Dividen saham $\left(\mathrm{D}_{\mathrm{it}}\right)$ adalah dividen saham "i” LQ45 Bursa Efek Indonesia pada periode ke-t (periode $\mathrm{cum}$ ).

Return Pasar:

$R_{M, t}=\frac{I H S G_{t}-I H S G_{t-1}}{I H S G_{t-1}}$ 


$$
R_{M, t}=\frac{I H S G_{t}-I H S G_{t-1}}{I H S G_{t-1}}
$$

Keterangan:

Return pasar $\left(\mathrm{R}_{\mathrm{M}, \mathrm{t}}\right)$ adalah tingkat return dari Indeks Harga Saham Gabungan Bursa Efek Indonesia pada waktu ke-t.

Indeks Harga Saham Gabungan adalah:

$\mathrm{IHSG}_{\mathrm{t}}=$ Indeks Harga Saham Gabungan Bursa Efek Indonesia pada saat penutupan minggu ke-t; $\mathrm{IHSG}_{\mathrm{t}-1}=$ Indeks Harga Saham Gabungan Bursa Efek Indonesia pada saat penutupan minggu ke-t-1.

\section{METODA PEMILIHAN PERUSAHAAN}

Perusahaan-perusahaan yang terpilih dalam penelitian ini merupakan perusahaan yang tercatat dalam publikasi Bursa Efek Indonesia (Indonesia Stock Exchange) sebagai saham-saham yang termasuk dalam indeks LQ45 bulan FebruariJuli 2014. Metoda yang digunakan adalah metodajudgement sampling. Judgement sampling adalah purposive sampling dengan kriteria berupa suatu pertimbangan tertentu (Hartono 2004). Pertimbangan dipilihnya saham-saham yang termasuk dalam indeks LQ45 sebagai berikut.

1. Saham-saham tersebut aktif ditransaksikan dengan nilai yang tinggi, memiliki kondisi keuangan yang bagus dan berprospek untuk mengalami pertumbuhan.

2. Untuk mengurangi bias pada data penelitian secara statistik karena tidak diperdagangkannya saham selama periode waktu tertentu.

Perusahaan-perusahaan yang terpilih dapat dilihat pada Tabel 2.

Tabel 2

Perusahaan LQ 45 berdasarkan Bursa Efek Indonesia Periode Februari-Juli 2014

\begin{tabular}{ccc}
\hline No & Kode Saham & Nama Perusahaan \\
\hline 1 & AALI & Astra Agro Lestari Tbk. \\
2 & ADHI & Adhi Karya Tbk. \\
3 & ADRO & Adaro Energy Tbk. \\
4 & AKRA & AKR Corporindo Tbk. \\
5 & ASII & Astra International Tbk. \\
6 & ASRI & Alam Sutera Realty Tbk. \\
7 & BBCA & Bank Central Asia Tbk. \\
8 & BBNI & Bank Negara Indonesia Tbk. \\
9 & BBRI & Bank Rakyat Indonesia Tbk. \\
10 & BDMN & Bank Danamon Tbk. \\
\hline
\end{tabular}

Tabel 2 (Lanjutan) 
Perusahaan LQ 45 berdasarkan Bursa Efek Indonesia Periode Februari-Juli 2014

\begin{tabular}{|c|c|c|}
\hline No & Kode Saham & Nama Perusahaan \\
\hline 11 & BKSL & Sentul City Tbk. \\
\hline 12 & BMRI & Bank Mandiri Tbk. \\
\hline 13 & BMTR & Global Mediacom Tbk. \\
\hline 14 & BSDE & Bumi Serpong Damai Tbk. \\
\hline 15 & CPIN & Charoen Pokphand Indonesia Tbk. \\
\hline 16 & CTRA & Ciputra Development Tbk. \\
\hline 17 & EXCL & XL Axiata Tbk. \\
\hline 18 & GGRM & Gudang Garam Tbk. \\
\hline 19 & HRUM & Harum Energy Tbk. \\
\hline 20 & ICBP & Indofood CBP Sukses Makmur Tbk. \\
\hline 21 & INDF & Indofood Sukses Makmur Tbk. \\
\hline 22 & INTP & Indocement Tunggal Prakasa Tbk. \\
\hline 23 & ITMG & Indo Tambangraya Megah Tbk. \\
\hline 24 & JSMR & Jasa Marga Tbk. \\
\hline 25 & KLBF & Kalbe Farma Tbk. \\
\hline 26 & LPKR & Lippo Karawaci Tbk. \\
\hline 27 & LSIP & PP London Sumatera Tbk. \\
\hline 28 & MAIN & Malindo Feedmill Tbk. \\
\hline 29 & MLPL & Multipolar Tbk. \\
\hline 30 & MNCN & Media Nusantara Citra Tbk. \\
\hline 31 & PGAS & Perusahaan Gas Negara Tbk. \\
\hline 32 & PTBA & Tambang Batubara Bukit Asam Tbk. \\
\hline 33 & PTPP & Pembangunan Perumahan Tbk. \\
\hline 34 & PWON & Pakuwon Jati Tbk. \\
\hline 35 & SMGR & Semen Indonesia Tbk. \\
\hline 36 & SMRA & Summarecon Agung Tbk. \\
\hline 37 & SSIA & Surya Semesta Internusa Tbk. \\
\hline 38 & TAXI & Express Transindo Utama Tbk. \\
\hline 39 & TBIG & Tower Bersama Infrastructure Tbk. \\
\hline 40 & TLKM & Telekomunikasi Indonesia Tbk. \\
\hline 41 & UNTR & United Tractors Tbk. \\
\hline 42 & UNVR & Unilever Indonesia Tbk. \\
\hline 43 & VIVA & Visi Media Asia Tbk. \\
\hline 44 & WIKA & Wijaya Karya Tbk. \\
\hline 45 & WSKT & Waskita Karya Tbk. \\
\hline
\end{tabular}

Sumber: Bursa Efek Indonesia

\section{SUMBER DATA DAN PERIODE PENELITIAN}

Sumber data yang digunakan dalam penelitian ini adalah, (1) Indeks Harga Saham Gabungan mingguan diperoleh dari situs finance.yahoo.com; (2) harga saham mingguan diperoleh dari situs finance.yahoo.com; (3) data perusahaan dan dividen 
saham diperoleh dari publikasi Bursa Efek Indonesia IDX LQ45 bulan Februari 2014.

Periode penelitian ini selama tiga tahun mulai dari 1 Januari 2010-30 Desember 2013 untuk return saham mingguan. Penggunaan data harian akan menghasilkan bias yang berhubungan dengan non-trading, bid-ask spread, nonsynchronous trading dan lain sebagainya yang mungkin akan menyebabkan hasil variance ratio agak bias (Lo dan Mackinlay 1988). Dalam melakukan perhitungan untuk return saham 1 Januari 2010 digunakan data satu minggu sebelumnya sebagai acuan, yaitu 28 Desember 2009. Untuk saham-saham yang baru listing, maka akan disesuaikan untuk pengolahan data selama periode pengamatan. Saham-saham tersebut sebagai berikut, (1) Harum Energy Tbk (HRUM) tercatat tanggal 6 Oktober 2010; (2) Pembangunan Perumahan Tbk (PTPP) tercatat tanggal 9 Februari 2010; (3) Express Transindo Utama Tbk (TAXI) tercatat tanggal 2 November 2012; (4) Tower Bersama Infrastructure Tbk (TBIG) tercatat tanggal 26 Oktober 2010; (5) Visi Media Asia Tbk (VIVA) tercatat tanggal 21 November 2011; (5) Waskita Karya Tbk (WSKT) tercatat tanggal 19 Desember 2012.

\section{TAHAPAN PERHITUNGAN DAN PENGOLAHAN DATA}

\section{Perhitungan Data}

Berikut adalah tahapan perhitungan data:

1. Penutupan nilai Indeks Harga Saham Gabungan mingguan dihitung dengan rumus return pasar.

2. Penutupan harga saham terpilih secara mingguan dihitung dengan rumus return saham.

\section{Alur Pengolahan Data}

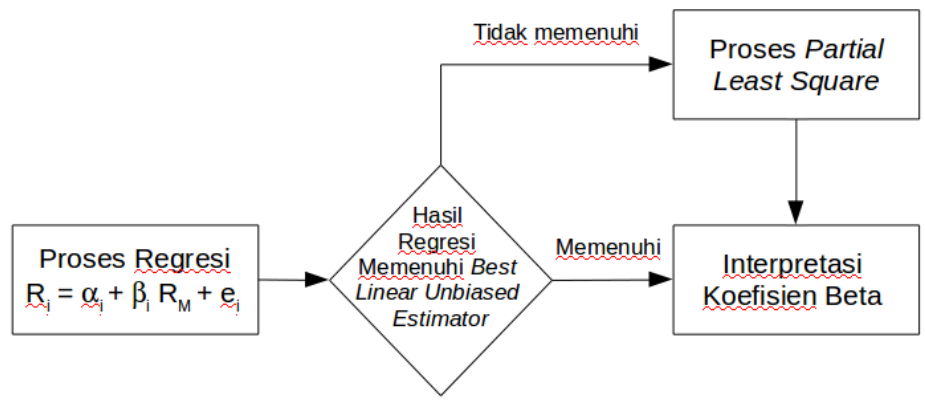

Gambar 1

Alur Pengolahan Data

Pengolahan data dimulai dengan meregresikan data return IHSG sebagai variabel bebas dengan data return saham LQ45 yang merupakan variabel dependen. Setelah itu dilakukan uji normalitas. Permasalahan autokorelasi, dan heteroskesdastisitas telah teratasi dengan menggunakan metodaNewey-West dalam Eviews. Persamaan-persamaan tersebut kemudian diuji dengan metodaJarque- 
Berauntuk mengetahui normalitas. Persamaan-persamaan yang tidak memenuhi asumsi normalitas akan diproses ulang dengan menggunakan Partial Least Square. Secara sederhana proses digambarkan pada Gambar 1.

\section{ANALISIS DAN PEMBAHASAN}

Hasil keluaran statistik menunjukkan bahwa semua persamaan bersifat linier. Hal ini dapat diketahui dari semua hasil probabilitas uji-F nilainya di bawah 0,05 . Hal-hal lain seperti probabilitas uji-t, Jarque-Beradan nilai probabilitas Jarque-Bera dapat dilihat pada Tabel 3.

Tabel 3

Hasil Regresi Linier

\begin{tabular}{|c|c|c|c|c|c|}
\hline \multirow[b]{2}{*}{ No } & \multicolumn{5}{|c|}{$\begin{array}{c}\text { Method: Least Squares } \\
\text { Newey-West HAC Standard Errors \& Covariance (lag truncation=4) } \\
\text { Program: Eviews }\end{array}$} \\
\hline & Persamaan & $\begin{array}{c}\text { Probabilitas } \\
\text { (F-statistic) }\end{array}$ & $\begin{array}{c}\text { Probabilitas } \beta \\
\text { (t-statistic) }\end{array}$ & Jarque-Bera & $\begin{array}{c}\text { Probabilitas } \\
\text { (Jarque-Bera) }\end{array}$ \\
\hline 1 & $\begin{array}{l}\text { R_AALI }=0,0001771223452+ \\
0,7638536376 \text { R_IHSG }\end{array}$ & 0,000000 & 0,0004 & 60,25466 & 0,000000 \\
\hline 2 & $\begin{array}{l}\text { R_ADHI = 0,005637075976 + } \\
1,441740024 \text { R_IHSG }\end{array}$ & 0,000000 & 0,0000 & 83,13169 & 0,000000 \\
\hline 3 & $\begin{array}{l}\text { R_ADRO }=-0,003239148385+ \\
0,9777300225 \text { R_IHSG }\end{array}$ & 0,000000 & 0,0001 & 129,6113 & 0,000000 \\
\hline 4 & $\begin{array}{l}\text { R_AKRA = 0,005860547679 + } \\
\text { 1,233648668 R_IHSG }\end{array}$ & 0,000000 & 0,0000 & 7,061859 & 0,029278 \\
\hline 5 & $\begin{array}{l}\text { R_ASII = -0,003729272689 + } \\
1,372195376 \text { R_IHSG }\end{array}$ & 0,000000 & 0,0000 & 163385,8 & 0,000000 \\
\hline 6 & $\begin{array}{l}\text { R_ASRI }=0,00557953941+ \\
1,444445972 \text { R_IHSG }\end{array}$ & 0,000000 & 0,0000 & 44,06839 & 0,000000 \\
\hline 7 & $\begin{array}{l}\text { R_BBCA = 0,001236562178 + } \\
1,059105594 \text { R_IHSG }\end{array}$ & 0,000000 & 0,0000 & 4,508939 & $\begin{array}{l}0,104929 \\
\text { (normal) }\end{array}$ \\
\hline 8 & $\begin{array}{l}\text { R_BBNI }=0,0009493753489+ \\
1,344456116 \text { R_IHSG }\end{array}$ & 0,000000 & 0,0000 & 321,4508 & 0,000000 \\
\hline 9 & $\begin{array}{l}\text { R_BBRI = -0,002131098203 + } \\
1,419433185 \text { R_IHSG }\end{array}$ & 0,000000 & 0,0000 & 32652,91 & 0,000000 \\
\hline 10 & $\begin{array}{l}\text { R_BDMN = -0,001486876873 + } \\
0,8157031971 \text { R_IHSG }\end{array}$ & 0,000000 & 0,0000 & 3644,691 & 0,000000 \\
\hline 11 & $\begin{array}{l}\text { R_BKSL }=0,001904395663+ \\
1,067424693 \text { R_IHSG }\end{array}$ & 0,000000 & 0,0000 & 1253,988 & 0,000000 \\
\hline 12 & $\begin{array}{l}\text { R_BMRI }=-0,0004140253387+ \\
1,490849946 \text { R_IHSG }\end{array}$ & 0,000000 & 0,0000 & 175,3571 & 0,000000 \\
\hline 13 & $\begin{array}{l}\text { R_BMTR = 0,009689398371 + } \\
1,195848571 \text { R_IHSG }\end{array}$ & 0,000000 & 0,0000 & 48,07667 & 0,000000 \\
\hline 14 & $\begin{array}{l}\text { R_BSDE }=0,0003513748761+ \\
1,314821484 \text { R_IHSG }\end{array}$ & 0,000000 & 0,0000 & 81,33651 & 0,000000 \\
\hline 15 & $\begin{array}{l}\text { R_CPIN }=0,003817280339+ \\
1,719330468 \text { R_IHSG }\end{array}$ & 0,000000 & 0,0000 & 24086,77 & 0,000000 \\
\hline
\end{tabular}


Tabel 3 (Lanjutan)

Hasil Regresi Linier

\begin{tabular}{|c|c|c|c|c|c|}
\hline & Newey-West HAC Stan & $\begin{array}{l}\text { Method: Leas } \\
\text { adard Errors \& } \\
\text { Program: I }\end{array}$ & $\begin{array}{l}\text { Squares } \\
\text { Covariance (las } \\
\text { views }\end{array}$ & truncation=4) & \\
\hline No & Persamaan & $\begin{array}{c}\text { Probabilitas } \\
\text { (F-statistic) }\end{array}$ & $\begin{array}{l}\text { Probabilitas } \beta \\
\text { (t-statistic) }\end{array}$ & Jarque-Bera & $\begin{array}{l}\text { Probabilitas } \\
\text { (Jarque- } \\
\text { Bera) }\end{array}$ \\
\hline $16 \mathrm{~F}$ & $\begin{array}{l}\text { R_CTRA = 0,002255056915 + } \\
1,316026035 \text { R_IHSG }\end{array}$ & 0,000000 & 0,0000 & 5907,169 & 0,000000 \\
\hline $17 \mathrm{~F}$ & $\begin{array}{l}\text { R_EXCL = 0,004616142082 + } \\
0,7258578485 \text { R_IHSG }\end{array}$ & 0,000001 & 0,0000 & 42,57537 & 0,000000 \\
\hline 18 & $\begin{array}{l}\text { R_GGRM }=0,002415617515+ \\
0,8855164465 \text { R_IHSG }\end{array}$ & 0,000000 & 0,0000 & 26,03798 & 0,000002 \\
\hline $19 \mathrm{~F}$ & $\begin{array}{l}\text { R_HRUM = -0,002466541394 + } \\
0,5844020664 \text { R_IHSG }\end{array}$ & 0,001236 & $\begin{array}{c}0,0612 \\
\text { (tidak } \\
\text { signifikan) }\end{array}$ & 2,758205 & $\begin{array}{c}0,251804 \\
\text { (normal) }\end{array}$ \\
\hline $20 \mathrm{~F}$ & $\begin{array}{l}\text { R_ICBP }=0,003646127269+ \\
1,016220781 \text { R_IHSG }\end{array}$ & 0,000000 & 0,0000 & 35,59867 & 0,000000 \\
\hline 21 & $\begin{array}{l}\text { R_INDF }=0,001487879072+ \\
1,081479582 \text { R_IHSG }\end{array}$ & 0,000000 & 0,0000 & 6,333703 & 0,042136 \\
\hline 22 & $\begin{array}{l}\text { R_INTP = -0,0001198360205 + } \\
1,135982533 \text { R_IHSG }\end{array}$ & 0,000000 & 0,0000 & 3,048247 & $\begin{array}{c}0,217812 \\
\text { (normal) }\end{array}$ \\
\hline 23 & $\begin{array}{l}\text { R_ITMG }=-0,0008750077335+ \\
0,9813767415 \text { R_IHSG }\end{array}$ & 0,000000 & 0,0000 & 46,96017 & 0,000000 \\
\hline 24 & $\begin{array}{l}\text { R_JSMR =0,003545588167+ } \\
0,7644110981 \text { R_IHSG }\end{array}$ & 0,000000 & 0,0000 & 338,8209 & 0,000000 \\
\hline 25 & $\begin{array}{l}\text { R_KLBF }=0,001826770619+ \\
1,320391549 \text { R_IHSG }\end{array}$ & 0,000000 & 0,0000 & 79010,60 & 0,000000 \\
\hline 26 & $\begin{array}{l}\text { R_LPKR = 0,001438201664 + } \\
1,238576385 \text { R_IHSG }\end{array}$ & 0,000000 & 0,0000 & 62,13135 & 0,000000 \\
\hline 27 & $\begin{array}{l}\text { R_LSIP }=-0,003755692353+ \\
0,9382395375 \text { R_IHSG }\end{array}$ & 0,000012 & 0.0003 & 24132,75 & 0,000000 \\
\hline 28 & $\begin{array}{l}\text { R_MAIN = 0,01104631537 + } \\
1,148961434 \text { R_IHSG }\end{array}$ & 0,000048 & 0,0000 & 5804,757 & 0,000000 \\
\hline 29 & $\begin{array}{l}\text { R_MLPL = 0,01188568949 + } \\
1,115486669 \text { R_IHSG }\end{array}$ & 0,000896 & 0,0000 & 17036,25 & 0,000000 \\
\hline 30 & $\begin{array}{l}\text { R_MNCN = 0,01178976998 + } \\
1,21865766 \text { R_IHSG }\end{array}$ & 0,000000 & 0,0000 & 121,7349 & 0,000000 \\
\hline 31 & $\begin{array}{l}\text { R_PGAS }=-0,0005510463342+ \\
1,069256647 \text { R_IHSG }\end{array}$ & 0,000000 & 0,0000 & 29,63705 & 0,000000 \\
\hline 32 & $\begin{array}{l}\text { R_PTBA }=-0,003436784997+ \\
1,056676925 \text { R_IHSG }\end{array}$ & 0,000000 & 0,0001 & 121,1486 & 0,000000 \\
\hline 33 & $\begin{array}{l}\text { R_PTPP = 0,002865964879 + } \\
1,361757679 \text { R_IHSG }\end{array}$ & 0,000000 & 0,0001 & 1447,337 & 0,000000 \\
\hline 34 & $\begin{array}{l}\text { R_PWON = -0,001400512923 + } \\
1,020840297 \text { R_IHSG }\end{array}$ & 0,000000 & 0,0000 & 32944,48 & 0,000000 \\
\hline 35 & $\begin{array}{l}\text { R_SMGR = 0,001473542787 + } \\
1,094357992 \text { R_IHSG }\end{array}$ & 0,000000 & 0,0000 & 7,388608 & 0,024865 \\
\hline 36 & $\begin{array}{l}\text { R_SMRA = 0,0006906721642+ } \\
1,261139617 \text { R_IHSG }\end{array}$ & 0,000000 & 0,0000 & 2693,147 & 0,000000 \\
\hline
\end{tabular}


Tabel 3 (Lanjutan)

Hasil Regresi Linier

\begin{tabular}{|c|c|c|c|c|c|}
\hline \multirow[b]{2}{*}{ No } & \multicolumn{4}{|c|}{$\begin{array}{c}\text { Method: Least Squares } \\
\text { Newey-West HAC Standard Errors \& Covariance (lag truncation=4) } \\
\text { Program: Eviews }\end{array}$} & \multirow[b]{2}{*}{$\begin{array}{l}\text { Probabilitas } \\
\text { (Jarque- } \\
\text { Bera) }\end{array}$} \\
\hline & Persamaan & $\begin{array}{c}\text { Probabilitas } \\
\text { (F-statistic) }\end{array}$ & $\begin{array}{c}\text { Probabilitas } \beta \\
\text { (t-statistic) }\end{array}$ & Jarque-Bera & \\
\hline 37 & $\begin{array}{l}\text { R_SSIA }=0,006498288913+ \\
1,095800339 \text { R_IHSG }\end{array}$ & 0,000010 & 0,0001 & 7449,323 & 0,000000 \\
\hline 38 & $\begin{array}{l}\text { R_TAXI }=0,01693234908+ \\
1,494925611 \text { R_IHSG }\end{array}$ & 0,000039 & 0,0086 & 2,161495 & $\begin{array}{r}0,339342 \\
\text { (normal) }\end{array}$ \\
\hline 39 & $\begin{array}{l}\text { R_TBIG }=0,005682362653+ \\
0,4429740062 \text { R_IHSG }\end{array}$ & 0,000701 & 0,0093 & 7,775822 & 0,020488 \\
\hline 40 & $\begin{array}{l}\text { R_TLKM }=-0,003767535396+ \\
0,660069138 \text { R_IHSG }\end{array}$ & 0,000235 & 0,0000 & 106566,3 & 0,000000 \\
\hline 41 & $\begin{array}{l}\text { R_UNTR }=-0,0006465210395+ \\
1,306218058 \text { R_IHSG }\end{array}$ & 0,000000 & 0,0000 & 12,52722 & 0,001904 \\
\hline 42 & $\begin{array}{l}\text { R_UNVR }=0,003636143128+ \\
0,7225560269 \text { R_IHSG }\end{array}$ & 0,000000 & 0,0000 & 69,62094 & 0,000000 \\
\hline 43 & $\begin{array}{l}\text { R_VIVA }=-0,002846619019+ \\
1,711138202 \text { R_IHSG }\end{array}$ & 0,000098 & 0,0173 & 42,67817 & 0,000000 \\
\hline 44 & $\begin{array}{l}\text { R_WIKA }=0,006554543092+ \\
1,224481093 \text { R_IHSG }\end{array}$ & 0,000000 & 0,0000 & 396,9425 & 0,000000 \\
\hline 45 & $\begin{array}{l}\text { R_WSKT }=0,002296989986+ \\
1,903882952 \text { R_IHSG }\end{array}$ & 0,000000 & 0,0005 & 2,268051 & $\begin{array}{l}0,321736 \\
\text { (normal) }\end{array}$ \\
\hline
\end{tabular}

Sumber: data diolah peneliti

Kemudian, setelah dilakukan uji normalitas dengan metodaJarque-Bera, maka terdapat 40 dari 45 persamaan terkendala permasalahan normalitas. Nilai probabilitas untuk Jarque-Bera di bawah 0,05. Adapun persamaan yang bebas dari permasalahan normalitas sebagai berikut (nilai probabilitas Jarque-Bera di atas $0,05)$ :

$\begin{array}{llll}\text { R_BBCA } & =0,001236562178 & +1,059105594 & \text { R_IHSG } \\ \text { R_HRUM } & =-0,002466541394 & +0,5844020664 & \text { R_IHSG } \\ \text { R_INTP } & =-0,0001198360205 & +1,135982533 & \text { R_IHSG } \\ \text { R_TAXI } & =0,01693234908 & +1,494925611 & \text { R_IHSG } \\ \begin{array}{l}\text { R_WSKT } \\ \text { (Huruf R merupakan simbol dari return) }\end{array} & +1,903882952 & \text { R_IHSG }\end{array}$

Dengan memperhatikan uji-t dari lima persamaan di atas, maka koefisien Beta untuk persamaan R_HRUM tidak signifikan dengan nilai signifikansi 0,0612 di atas 0,05 .

Empat puluh persamaan yang lain diproses ulang dengan metodaPartial Least Square untuk memprediksi nilai Beta. Dengan mempertimbangkan hasil 
keluaran dan dengan membandingkan besaran $t_{\text {hitung }}$ dengan $t_{\text {tabel }}$, maka ditemukan persamaan untuk R_ASII dan R_TLKM tidak signifikan. Hal ini dikarenakan $t_{\text {hitung }}$ untuk Beta dalam persamaan R_ASII sebesar 1,968588 dan $\mathrm{t}_{\text {hitung }}$ untuk Beta dalam persamaan R_TLKM sebesar 1,621300 yang lebih kecil daripada $t_{\text {tabel }}$ yang sebesar 1,971603 dengan derajat tingkat kebebasan (degree of freedom) 205. Hasil keluaran statistik untuk membandingkan $t_{\text {hitung }}$ dengan $t_{\text {tabel }}$ dalam menentukan signifikansi Beta R_IHSG untuk empat puluh persamaan dapat dilihat pada Tabel 4.

Tabel 4

Hasil Keluaran dengan Metoda Partial Least Square

\begin{tabular}{|c|c|c|c|c|c|}
\hline \multirow[b]{2}{*}{ No } & \multicolumn{4}{|c|}{$\begin{array}{l}\text { Method: Partial Least Squares } \\
\text { SMARTPLS Ver: } 2.0 . \mathrm{M} 3\end{array}$} & \multirow[b]{2}{*}{ Signifikansi } \\
\hline & $\begin{array}{l}\text { Kode } \\
\text { Saham }\end{array}$ & $\stackrel{\beta}{\beta}$ & t-statistic & $\begin{array}{c}\text { t-table } \\
(\alpha=5 \%, d f=205 \\
\text { kecuali disebutkan } \\
\text { lain) }\end{array}$ & \\
\hline 1 & AALI & 0,362912 & 2,835120 & 1,971603 & signifikan \\
\hline 2 & ADHI & 0,488466 & 4,997936 & 1,971603 & signifikan \\
\hline 3 & ADRO & 0,441421 & 3,664105 & 1,971603 & signifikan \\
\hline 4 & AKRA & 0,535720 & 7,121332 & 1,971603 & signifikan \\
\hline 5 & ASII & 0,451791 & 1,968588 & 1,971603 & tidak signifikan \\
\hline 6 & ASRI & 0,529916 & 4,717323 & 1,971603 & signifikan \\
\hline 7 & BBNI & 0,698444 & 9,651404 & 1,971603 & signifikan \\
\hline 8 & BBRI & 0,653686 & 6,087332 & 1,971603 & signifikan \\
\hline 9 & BDMN & 0,385402 & 3,221104 & 1,971603 & signifikan \\
\hline 10 & BKSL & 0,368699 & 3,551784 & 1,971603 & signifikan \\
\hline 11 & BMRI & 0,801047 & 21,585864 & 1,971603 & signifikan \\
\hline 12 & BMTR & 0,447433 & 4,859544 & 1,971603 & signifikan \\
\hline 13 & BSDE & 0,520334 & 5,318070 & 1,971603 & signifikan \\
\hline 14 & CPIN & 0,484458 & 3,062422 & 1,971603 & signifikan \\
\hline 15 & CTRA & 0,430555 & 2,521784 & 1,971603 & Signifikan \\
\hline 16 & EXCL & 0,332722 & 3,114361 & 1,971603 & signifikan \\
\hline 17 & GGRM & 0,442391 & 4,360350 & 1,971603 & signifikan \\
\hline 18 & ICBP & 0,526312 & 5,919955 & 1,971603 & signifikan \\
\hline 19 & INDF & 0,615999 & 6,369502 & 1,971603 & signifikan \\
\hline 20 & ITMG & 0,468163 & 4,420253 & 1,971603 & signifikan \\
\hline 21 & JSMR & 0,517666 & 5,784597 & 1,971603 & signifikan \\
\hline 22 & KLBF & 0,448208 & 2,693647 & 1,971603 & signifikan \\
\hline 23 & LPKR & 0,493207 & 4,847107 & 1,971603 & signifikan \\
\hline 24 & LSIP & 0,299044 & 2,830956 & 1,971603 & signifikan \\
\hline 25 & MAIN & 0,278724 & 3,269930 & 1,971603 & signifikan \\
\hline 26 & MLPL & 0,229164 & 2,135851 & 1,971603 & signifikan \\
\hline 27 & MNCN & 0,410320 & 4,864316 & 1,971603 & signifikan \\
\hline 28 & PGAS & 0,599567 & 9,001862 & 1,971603 & signifikan \\
\hline 29 & PTBA & 0,499271 & 4,186589 & 1,971603 & signifikan \\
\hline 30 & PTPP & 0,435937 & 3,336482 & $\begin{array}{l}1,972017 \\
(\mathrm{df}=198)\end{array}$ & Signifikan \\
\hline
\end{tabular}


Tabel 4 (Lanjutan)

Hasil Keluaran dengan Metoda Partial Least Square

\begin{tabular}{|c|c|c|c|c|c|}
\hline \multirow[b]{2}{*}{ No } & \multicolumn{4}{|c|}{$\begin{array}{l}\text { Method: Partial Least Squares } \\
\text { SMARTPLS Ver: } 2.0 . \mathrm{M3}\end{array}$} & \multirow[b]{2}{*}{ Signifikansi } \\
\hline & $\begin{array}{c}\text { Kode } \\
\text { Saham }\end{array}$ & $\stackrel{\beta}{\text { R_IHSG }}$ & t-statistic & $\begin{array}{c}\text { t-table } \\
(\alpha=5 \%, d f=205 \\
\text { kecuali disebutkan } \\
\text { lain })\end{array}$ & \\
\hline 31 & PWON & 0,341572 & 2,200154 & 1,971603 & signifikan \\
\hline 32 & SMGR & 0,636824 & 8,942018 & 1,971603 & signifikan \\
\hline 33 & SMRA & 0,471815 & 2,609651 & 1,971603 & signifikan \\
\hline 34 & SSIA & 0,301291 & 2,377967 & 1,971603 & signifikan \\
\hline 35 & TBIG & 0,262011 & 2,663275 & $\begin{array}{l}1,974716 \\
(\mathrm{df}=162)\end{array}$ & signifikan \\
\hline 36 & TLKM & 0,253006 & 1,621300 & 1,971603 & tidak signifikan \\
\hline 37 & UNTR & 0,653977 & 9,998156 & 1,971603 & signifikan \\
\hline 38 & UNVR & 0,428315 & 3,723572 & 1,971603 & signifikan \\
\hline 39 & VIVA & 0,364361 & 2,955464 & $\begin{array}{l}1,982383 \\
(\mathrm{df}=107)\end{array}$ & signifikan \\
\hline 40 & WIKA & 0,524007 & 5,375237 & $\begin{array}{l}2,007584 \\
(\mathrm{df}=51)\end{array}$ & signifikan \\
\hline
\end{tabular}

Sumber: data diolah peneliti

Nilai $\mathrm{t}_{\text {tabel }}$ hasil perhitungan dengan program LibreOffice Calc dapat dilihat pada Tabel 5.

Tabel 5

Tabel nilai t dengan $\alpha=5 \%$, uji 2 sisi

\begin{tabular}{cccccc}
\hline df & Value & df & value & Df & value \\
\hline 205 & 1,971603 & 164 & 1,974535 & 75 & 1,992102 \\
204 & 1,971661 & 163 & 1,974625 & 74 & 1,992543 \\
203 & 1,971719 & 162 & 1,974716 & 73 & 1,992997 \\
202 & 1,971777 & 161 & 1,974808 & 72 & 1,993464 \\
201 & 1,971837 & 160 & 1,974902 & 71 & 1,993943 \\
200 & 1,971896 & & & 70 & 1,994437 \\
199 & 1,971957 & 110 & 1,981765 & 69 & 1,994945 \\
198 & 1,972017 & 109 & 1,981967 & 68 & 1,995469 \\
197 & 1,972079 & 108 & 1,982173 & 67 & 1,996008 \\
196 & 1,972141 & 107 & 1,982383 & 66 & 1,996564 \\
195 & 1,972204 & 106 & 1,982597 & 65 & 1,997138 \\
194 & 1,972268 & 105 & 1,982815 & 64 & 1,99773 \\
193 & 1,972332 & 104 & 1,983038 & 63 & 1,998341 \\
192 & 1,972396 & 103 & 1,983264 & 62 & 1,998972 \\
191 & 1,972462 & 102 & 1,983495 & 61 & 1,999624 \\
190 & 1,972528 & 101 & 1,983731 & 60 & 2,000298 \\
189 & 1,972595 & 100 & 1,983972 & 59 & 2,000995 \\
\hline
\end{tabular}


Tabel 5 (Lanjutan)

Tabel nilai t dengan $\alpha=5 \%$, uji 2 sisi

\begin{tabular}{|c|c|c|c|c|c|}
\hline $\mathrm{df}$ & Value & df & value & Df & value \\
\hline 188 & 1,972663 & 99 & 1,984217 & 58 & 2,001717 \\
\hline 187 & 1,972731 & 98 & 1,984467 & 57 & 2,002465 \\
\hline 186 & 1,9728 & 97 & 1,984723 & 56 & 2,003241 \\
\hline 185 & 1,97287 & 96 & 1,984984 & 55 & 2,004045 \\
\hline 184 & 1,972941 & 95 & 1,985251 & 54 & 2,004879 \\
\hline 183 & 1,973012 & 94 & 1,985523 & 53 & 2,005746 \\
\hline 182 & 1,973084 & 93 & 1,985802 & 52 & 2,006647 \\
\hline 181 & 1,973157 & 92 & 1,986086 & 51 & 2,007584 \\
\hline 180 & 1,973231 & 91 & 1,986377 & 50 & 2,008559 \\
\hline 179 & 1,973305 & 90 & 1,986675 & & \\
\hline 178 & 1,973381 & 89 & 1,986979 & & \\
\hline 177 & 1,973457 & 88 & 1,98729 & & \\
\hline 176 & 1,973534 & 87 & 1,987608 & & \\
\hline 175 & 1,973612 & 86 & 1,987934 & & \\
\hline 174 & 1,973691 & 85 & 1,988268 & & \\
\hline 173 & 1,973771 & 84 & 1,98861 & & \\
\hline 172 & 1,973852 & 83 & 1,98896 & & \\
\hline 171 & 1,973934 & 82 & 1,989319 & & \\
\hline 170 & 1,974017 & 81 & 1,989686 & & \\
\hline 169 & 1,9741 & 80 & 1,990063 & & \\
\hline 168 & 1,974185 & 79 & 1,99045 & & \\
\hline 167 & 1,974271 & 78 & 1,990847 & & \\
\hline 166 & 1,974358 & 77 & 1,991254 & & \\
\hline 165 & 1,974446 & 76 & 1,991673 & & \\
\hline
\end{tabular}

Hasil dari penelitian ini didasarkan pada data mingguan yang berbeda dengan yang dilakukan oleh Pasaribu (2009) mengenai koreksi Beta yang bias. Dengan menggunakan data mingguan seperti yang disarankan oleh Lo dan Mackinlay (1988).

Dari 45 saham LQ45 yang diprediksi risiko sistematiknya, ada tiga saham yang tidak berhasil diprediksi secara signifikan. Ada hal-hal lain di luar model yang lebih berpengaruh terhadap saham Astra International Tbk (ASII), Harum Energy Tbk (HRUM) dan Telekomunikasi Indonesia Tbk (TLKM). Risiko sistematik terbesar dimiliki oleh Waskita Karya Tbk (WSKT) sebesar 1,903882952, kemudian diikuti oleh Express Transindo Utama Tbk (TAXI), Indocement Tunggal Prakasa Tbk (INTP), Bank Central Asia Tbk (BBCA). Peringkat besarnya risiko sistematik dapat dilihat pada Tabel 6.

Hasil nilai risiko sistematik relatif tinggi dari hasil pengujian parametrik, namun hasil dari proses non-parametrik tidak dapat diabaikan. Saham-saham perbankan memiliki risiko sistematik yang relatif besar dibandingkan dengan sahamsaham lain. Hal ini ditunjukkan dalam Tabel 6, Bank Central Asia Tbk (BBCA), 
Bank Mandiri Tbk (BMRI), Bank Negara Indonesia Tbk (BBNI) dan Bank Rakyat Indonesia Tbk (BBRI) menduduki peringkat empat, lima, enam dan delapan dari 42.

Tabel 6

Peringkat Hasil Prediksi Risiko Sistematik (Beta)

\begin{tabular}{|c|c|c|c|c|c|}
\hline Peringkat & Kode Saham & Beta & Peringkat & Kode Saham & Beta \\
\hline 1 & WSKT & 1,903882952 & 23 & ITMG & 0,468163 \\
\hline 2 & TAXI & 1,494925611 & 24 & KLBF & 0,448208 \\
\hline 3 & INTP & 1,135982533 & 25 & BMTR & 0,447433 \\
\hline 4 & $\mathrm{BBCA}$ & 1,059105594 & 26 & GGRM & 0,442391 \\
\hline 5 & BMRI & 0,801047 & 27 & ADRO & 0,441421 \\
\hline 6 & BBNI & 0,698444 & 28 & РТPP & 0,435937 \\
\hline 7 & UNTR & 0,653977 & 29 & CTRA & 0,430555 \\
\hline 8 & BBRI & 0,653686 & 30 & UNVR & 0,428315 \\
\hline 9 & SMGR & 0,636824 & 31 & MNCN & 0,41032 \\
\hline 10 & INDF & 0,615999 & 32 & BDMN & 0,385402 \\
\hline 11 & PGAS & 0,599567 & 33 & BKSL & 0,368699 \\
\hline 12 & AKRA & 0,53572 & 34 & VIVA & 0,364361 \\
\hline 13 & ASRI & 0,529916 & 35 & AALI & 0,362912 \\
\hline 14 & ICBP & 0,526312 & 36 & PWON & 0,341572 \\
\hline 15 & WIKA & 0,524007 & 37 & EXCL & 0,332722 \\
\hline 16 & BSDE & 0,520334 & 38 & SSIA & 0,301291 \\
\hline 17 & JSMR & 0,517666 & 39 & LSIP & 0,299044 \\
\hline 18 & PTBA & 0,499271 & 40 & MAIN & 0,278724 \\
\hline 19 & LPKR & 0,493207 & 41 & TBIG & 0,262011 \\
\hline 20 & ADHI & 0,488466 & 42 & MLPL & 0,229164 \\
\hline 21 & CPIN & 0,484458 & & & \\
\hline 22 & SMRA & 0,471815 & & & \\
\hline
\end{tabular}

Sumber: data diolah peneliti

Metoda non-parametrik merupakan alternatif yang dilakukan setelah asumsi normalitas tidak terpenuhi dalam pengambilan keputusan (inferensi) dalam model penelitian ini. Data outlier yang sekiranya mengganggu terpenuhinya normalitas tidak dimodifikasi atau dihilangkan. Dengan tidak melakukan treatment seperti yang telah disebutkan, masih ada lima persamaan yang memenuhi uji normalitas yang digunakan, yaitu Jarque-Bera. Jika menghilangkan atau memodifikasi data yang ada dikhawatirkan akan ada gejala (symptom) dari kondisi riil yang tidak terdeteksi.

\section{SIMPULAN}

Berdasarkan seluruh tahapan dalam penelitian ini, maka dapat disimpulkan:

1. Model data mingguan relatif lebih terhindar dari permasalahan teknis perdagangan dalam memprediksi risiko sistematik. 
2. Adanya faktor lain yang lebih berpengaruh terhadap return saham ASII, HRUM dan TLKM sehingga risiko sistematik tidak berpengaruh secara signifikan.

3. Saham-saham perbankan memiliki risiko sistematik yang relatif tinggi dalam emiten yang tergabung dalam indeks LQ45.

\section{DAFTAR PUSTAKA}

Bartholdy, J., dan P. Peare. 2001. The relative efficiency of beta estimates. Social Science Research Network. (March): 1-20.

Bernstein, P. L. 1992. Capital ideas. DalamHave we misinterpreted CAPM for 4years? A Theoretical Proof. Fan, S.C. 2004. Social Science Research Network: 1-19.

Brooks, C. 2008. Introductory Econometrics for Finance. Edisi ke Dua, New York: Cambridge University Press.

Bursa Efek Indonesia. 2014. IDX LQ45 February 2014. Jakarta: BEI.

Chan, L. K.C., Y. Hamao, dan J. Lakonishok. 1991. Fundamentals and stock returns in Japan. DalamHave we Misinterpreted CAPM for 40 years? A TheoreticalProof. $\quad$ Fan, S.C. 2004. Social Science Research Network: 119.

Fama, E. 1971. Efficient capital markets: A review of theory and empirical work.DalamHave we Misinterpreted CAPM for 40 years? A Theoretical Proof. Fan, S.C. 2004. Social Science Research Network: 1-19.

Fama, E.F., dan K. French. 1992. The cross section of expected stock returns.Dalam Have we Misinterpreted CAPM for 40 years? A Theoretical Proof.

Fan, S.C. 2004. Have we Misinterpreted CAPM for 40 years? A Theoretical Proof.Social Science Research Network.(September): 1-19.

Fama, E. F., dan K. R. French. 2003. The capital asset pricing model: Theory and evidence. CRSP Working Paper No. 550. Tuck Business School Working Paper No. 03-26 (August): 1-35.

Universitas Gadjah Mada, Pidato Pengukuhan Jabatan Guru Besar Fakultas Ekonomi. 2003. Risiko Sistematik (Beta):Berbagai Isu Pengestimasian danKeterterapannya dalam Penelitian Empirik. Tandelilin, E. Yogyakarta: UGM.

Hartono, J. 2009. Teori Portofolio dan Analisis Investasi. Edisi ke Enam. Yogyakarta:BPFE. 
Fan, S. C. 2004. Have we misinterpreted CAPM for 40 years? A Theoretical Proof. Social Science Research Network. (September): 1-19.

Fama, E.F., L. Fisher, M. Jensen, dan R. Roll. 1969. The adjustment of stock prices tonew information. Dalam Have we Misinterpreted CAPM for 40 years? A Theoretical Proof. Fan, S.C. 2004. Social Science Research Network. (September): 1-19.

Ghozali, I. 2008. Structural Equation Modelling Metoda Alternatif dengan Partial Least Square. Edisi ke Dua, Semarang: Badan Penerbit Universitas Diponegoro.

Hartono, J. 2004. Metodologi Penelitian Bisnis: Salah Kaprah dan Pengalamanpengalaman. Edisi ke Satu, Yogyakarta: BPFE.

Hartono, J., dan W. Abdillah. 2009. Konsep \& Aplikasi Partial Least Square untuk Penelitian Empiris. Edisi ke Satu, Yogyakarta: BPFE.

Lo, A., dan A. C. Mackinlay. 1988. Stock market prices do not follow random walk: Evidence from simple specification tests. Dalam Benarkah Pasar Modal Kita Efisien? Bukti dari Jakarta Stock Exchange. Utomo, D., dan Fuad. 2008. Jurnal Keuangan dan Perbankan.Vol.12 No.1(Agustus): 43-55.

Malkiel, B. G. 1990. A random walk down wall street. Dalam Have we Misinterpreted CAPM for 40 years? A Theoretical Proof. Fan, S.C. 2004. Social Science Research Network. (September): 1-19.

Manurung. A. H. 1996. Asset pricing model on the jakarta stock exchange: A nonparametric analysis. Dalam Bunga Rampai Kajian Teori Keuangan. 2002. Disunting oleh S. Husnan, E. Tandelilin, M. Asri, dan M.M. Hanafi. Yogyakarta: BPFE.

Pasaribu, R.B.F. 2009. Non-synchronous trading in indonesia stock exchange. Journal of Economics and Business. Vol. 3 No.2(July): 81-89. 
